慶應義塾大学学術情報リポジトリ

Keio Associated Repository of Academic resouces

\begin{tabular}{|c|l|}
\hline Title & $\begin{array}{l}\text { CD34 expression on long-term repopulating hematopoietic stem cells changes during } \\
\text { developmental stages. }\end{array}$ \\
\hline Sub Title & 長期造血再構築能を持つ造血幹細胞におけるCD34抗原の発現の発達に伴う推移 \\
\hline Author & 松岡, 佐保子(Matsuoka, Sahoko) \\
\hline Publisher & 慶應医学会 \\
\hline Publication year & 2003 \\
\hline Jtitle & 慶應医学 (Journal of the Keio Medical Society). Vol.80, No.2 (2003. 6),p.11- \\
\hline JaLC DOI & \\
\hline Abstract & \\
\hline Notes & 号外 \\
\hline Genre & Journal Article \\
\hline URL & https://koara.lib.keio.ac.jp/xoonips/modules/xoonips/detail.php?koara_id=AN00069296-2003060 \\
\hline
\end{tabular}

慶應義塾大学学術情報リポジトリ(KOARA)に掲載されているコンテンッの著作権は、それぞれの著作者、学会または出版社/発行者に帰属し、その権利は著作権法によって 保護されています。引用にあたっては、著作権法を遵守してご利用ください。

The copyrights of content available on the KeiO Associated Repository of Academic resources (KOARA) belong to the respective authors, academic societies, or publishers/issuers, and these rights are protected by the Japanese Copyright Act. When quoting the content, please follow the Japanese copyright act. 


\title{
CD34 expression on long-term repopulating hematopoietic stem cells changes during developmental stages. \\ (長期造血再構築能を持つ造血幹細胞におけるCD34抗原の発現の発達に伴う推移)
}

\author{
松岡佐保子
}

\section{内容の要旨}

CD34抗原は血液細胞、血管内皮細胞、胎生期の綫維芽細胞などに 発現が認められる糖蛋白であるが、CD34抗原を発現する細胞が、in vitroの実験系において様々な血液細胞への分化能を持つことが認め られたことから、CD34抗原は未分化な造血細胞が発現している最も 重要なマーカーと考えられるようになり、実際に造血幹細胞移植や 遺伝子治療などの臨床に用いられている。しかし、造血幹細胞が CD34抗原を発現しているか否かは未だ明らかになっていない。我々 はマウスの造血幹細胞におけるCD34抗原発現の発達に伴う推移につ いて、最近確立された競合的長期造血再構築能アッセイ法を用いて 検討した。

新生仔期マウスの骨髄細胞の移植実験では、分化抗原陰性c-Kit抗 原陽性CD34抗原陽性細胞を移植したマウスにおいて、末梢血中に移 植細胞由来の血液細胞が赤血球系、B細胞系、T細胞系全てで出現を 認め、分化抗原陰性c-Kit抗原陽性分画細胞中では造血再構築能をも つ造血幹細胞はCD34抗原を発現していることが明らかとなった。肝 臓および脾臟の細胞でも同様に造血幹細胞にはCD34抗原の発現が認

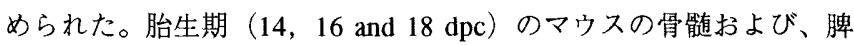
蔵の細胞を用いた実験でも、分化抗原陰性c-Kit抗原陽性CD34陽性細 胞に造血再構築能が認められた。

しかしながら成獣マウスの骨髄細胞について検討したところ、1 週秢のマウスでは新生仔マウス同様に造血幹細胞でCD34抗原の発現 が認められたが、その発現は加齢に伴い減弱し、16週秢ではCD34抗 原陰性の細胞を移植したマウスのみ造血再構築が認められた。さら に成獣マウスの分化抗原陰性c-Kit抗原陽性CD34陰性造血幹細胞が、 新生仔のCD34陽性造血幹細胞に由来しているか否かを明らかにする ため、新生仔 CD 34骨軥造血幹細胞を移植したレシピエントマウスよ り移植後 4 週目と 16 週目にその骨骾細胞をソーティングし second transplantationを施行したところ、移植後 4 週目のマウスではCD34陽 性細胞分画に造血幹細胞が認められていたが、移植後16週目のマウ スではCD34陰性細胞分画に造血幹細胞が含まれており、新生仔マウ 久の分化抗原陰性 $\mathrm{C}-\mathrm{Kit}$ 抗原陽性CD34陽性造血幹細胞は成獣の分化抗 原陰性C-Kit抗原陽性CD34陰性造血幹細胞に由来することが明らかと なった。コロニーアッセイではマウスの週㱓によらず造血前駆細胞 は分化抗原陰性c-Kit抗原陽性CD34+細胞分画に含まれていた。

以上の結果より、胎仔期扔よび新生仔期から成獣の早期までマウ スの造血幹細胞はCD34を発現しているが、以降加齢とともにその発 現は次第に減弱していくことが認められた。この結果は、CD34enriched細胞の移植や脺帯血移植など、用いられる細胞起源が多様化 してきている造血幹細胞移植の臨床において、細胞起源によりその 造血幹細胞の性状が異なることを示唆しており、非常に重要な意義 があると考えられた。

\section{論文審查の要旨}

CD34抗原は未分化な造血細胞で発現している最も重要なマーカー として、造血幹細胞移植や遺伝子治療などの臨床に用いられている。 しかし、自己複製能と多分化能を有する造血幹細胞がCD34抗原を発 現しているか否かは十分解明されていない。本研究ではマウス造血 幹細胞に扔けるCD34抗原発現の発達に伴う推移を、競合的長期造血 再構築能アッセイ法を用いて明らかにした。

新生仔期マウスの骨髄細胞の移植実験では、分化抗原陰性c-Kit抗 原陽性CD34抗原陽性細胞を移植したマウスにおいて、移植後 3 ヶ月 目の末梢血中に移植した細胞由来の顆粒球系、B細胞系、T細胞系の 細胞の出現を認め、造血再構築能をもつ造血幹細胞はCD34抗原を発 現していることが明らかとなった。肝蔵および脾臓の造血幹細胞で も同様にCD34抗原の発現が認められた。胎生期の肝臟でも、分化抗 原陰性C-Kit抗原陽性CD34抗原陽性細胞に造血再構築能が認められ た。

しかしながら成獣マウスの骨髄細胞では、1-4 週梌のマウスで は造血幹細胞でCD34抗原の発現が認められたが、その発現は加跉に 伴い減弱し、10週齢以降ではCD34抗原陰性の細胞を移植したマウス のみ造血再構築が認められた。さらに新生仔期の骨髄CD34抗原陽性 造血幹細胞を移植したレシピエントマウスより移植後 4 週目と16週 目にそのドナー由来の骨䯣細胞をソーティングして再移植した結果、 移植後 4 週目のマウスではCD34抗原陽性細胞分画に造血幹細胞が認 められていたが、移植後16週目のマウスではCD34抗原陰性細胞分画 に造血幹細胞が含まれて扮り、成獣マウスの分化抗原陰性c-Kit抗原 陽性CD34抗原陰性造血幹細胞は新生仔マウスのCD34抗原陽性造血 幹細胞に由来することが明らかとなった。コロニーアッセイではマ ウスの週齢によらず造血前駆細胞は分化抗原陰性c-Kit抗原陽性CD34 抗原陽性紏胞分画に含まれていた。

以上の結果より、マウスの造血幹細胞は胎仔期から成獣の早期ま でCD34抗原を発現しているが、以降加齢とともにその発現は減弱し ていくことが認められた。

審査では造血再構築能の評価として赤血球系や血小板巨核球系の 細胞を検討していない点や、移植する細胞を single cellにまで純化し てより詳細に性状解析をすることが望ましいという指摘がなされた。 また、本研究はマウスでの検討であるがヒトの造血幹細胞ではどう かという質問があり、これに対してヒトの造血細胞を免疫不全マウ スなどに移植する研究で、やはりCD34抗原陰性の造血幹細胞を認め ている報告があるが、その性状解析については未だ解明されていな い点が多く引き続き研究していくことが重要であると解答した。本 研究は造血幹細胞を経時的に詳細に解析することでその性状が変化 することを極めて明確に示しており、造血幹細胞移植に抢ける幹細 胞のソースが多様化してる現状を考えると非常に重要な研究である と評価された。

論文審査担当者 主査 内科学 池田 康夫

発生·分化生物学 須田 年生・生理学 岡野 栄之 先端医科学河上裕病理学 岡田保典

学力確認担当者：

審査委員長：須田 年生

試問日：平成15年 2 月 19 日 